Hooimeijer, P., Dieleman, F.M., \& Dam, van, J. (1988). Residential mobility of households in the reduction stage in The Netherlands. TESG, 79(5), 306-319. 


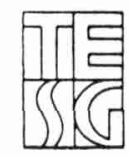

\title{
RESIDENTIAL MOBILITY OF HOUSEHOLDS IN THE REDUCTION STAGE IN THE NETHERLANDS
}

\author{
by \\ P. HOOIMEIJER*, F. M. DIELEMAN* \& J. VAN DAM* \\ Utrecht, The Netherlands
}

\section{Introduction}

By the year 2000, more than half of the total number of households in the Netherlands are expected to be in the 'reduction stage' of their life cycle. In a previous study we tried to estimate the number of households in the reduction stage more precisely, using methods of family demography and population projections published by the Central Bureau of Statistics (Hooimeijer \& Dieleman 1986). In the present study we have defined the reduction stage as the period of the life cycle ranging from the moment the first child leaves the parental home (in the Netherlands, when the mother is 47 years of age, on the average) until the moment the last member of the household leaves the market for independent housing or dies. If no major changes occur in the age at which children leave the parental home or in old-age mortality in the next decade, the number of households in the reduction stage can be expected to grow by about 400,000 between 1985 and 2000. The large population cohorts born in the decades after the Second World War are now beginning to enter the reduction stage of the life cycle and will be responsible for the expected growth in the coming twelve years.

In previous publications we estimated some of the effects of the ageing of the population on the housing market (Hooimeijer et al. 1986, 1987). We demonstrated that mobility and housing choice of households in the reduction

\footnotetext{
* Department of Geography, University of Utrecht, P.O. Box $80.115,3508$ TC Utrecht, The Netherlands.
}

Received March, 1988; revised July, 1988 stage differ markedly from the behaviour of households in the earlier stages of the life cycle and that the process of filtering in the housing market will change substantially with the ageing of the Dutch population.

For younger households the demand for extra space - which accompanies the growth of the family and the growth in income - is known to be a major force behind the process of housing adjustment (Clark et al. 1986). For households in the reduction stage the need for extra space will be less important or even nonexistent because the number of household members decreases. Often the income has also reached a more or less stable level by the age of 50. So (growth in) income will probably also be less important as a factor in residential mobility at the moment the household reaches the reduction stage of the life cycle. These may well be the major elements explaining the low mobility rate of households in the reduction stage. If the reduction stage is subdivided into the child-launching, empty-nest and widowhood phases, the mobility is especially low in the phase of child-launching. At this time, the extra space created by the reduction in household size is not a major reason to make an adjustment move to smaller housing. Probably many households in the child-launching and empty-nest phases want to retain this extra space as a guestroom for children, grandchildren and friends. Nor does the more or less stable income necessitate a move to smaller, less expensive housing in these phases of the reduction stage.

There seems to be a state of equilibrium between demand for housing space and quality 
and characteristics of the dwelling one occupies, particularly in the phase of childlaunching. This equilibrium slowly seems to turn into disequilibrium in the later phases of the reduction stage (cf. Hooimeijer \& Dieleman 1986). The mobility rate remains low in later phases of the reduction stage but is higher in comparison to the child-launching phase. Households that do move tend to choose smaller dwellings; an excess of space seems cumbersome at an older age when physical capacities decrease and the household is reduced in many instances to one person (cf. Hooimeijer et al. 1986). But the factors influencing the propensity of older households to move should be investigated more systematically to substantiate this line of reasoning.

The patterns of housing choice expressed by those households in the reduction stage that do move also tend to differ from the choice patterns of households in the earlier stages of the life cycle and seem to depend on other factors. In general, choice patterns are strongly influenced by previous tenure, especially in controlled housing markets such as those in the Netherlands and Sweden. Households living in the public sector have greater access to other housing in that sector than do households from the private rental and owner-occupied sectors (Deurloo et al. 1987). It is interesting to note that, like in North America and Britain, income is still a major determinant of dwelling choice in the Netherlands, despite the highly regulated structure of the housing market in this country (Kendig 1984, Clark 1986). Young, growing households move more from rental and multi-family housing towards single-family and home-ownership housing than vice versa, and income clearly acts as a constraint on this general pattern (Deurloo et al. 1987). But older households show a different choice pattern. They seem to have a greater preference for rental housing, and the role of income as a constraint on or determinant of choice may therefore be less important (Hooimeijer et al. 1987).

Although recent studies have considerably extended our knowledge of migration and mobility of older households (cf. Golant 1984, Barink \& Hooimeijer 1988), the links between the characteristics and housing situation of these households, the propensity to move, and the nature of their housing choice are not yet well understood. This study is designed to explicate some of these relationships more sys- tematically.

- Can the propensity to move of households in the reduction stage be related systematically to the housing situation and characteristics of these households?

- How do tenure, income, life cycle, and other factors influence the housing choice of households in the reduction stage that make an adjustment move? Is the housing choice of households in the reduction stage driven by other factors than those implicated in the housing choice of younger households?

\section{Research design and data}

The data file that formed the basis of earlier and related investigations (Hooimeijer et al. 1986, Deurloo 1987) was also used here. The data of the National Housing Needs Survey 1981 (WBO81) are derived from a one-percent sample of all households in the Netherlands in 1981, carried out under the auspices of the Central Bureau of Statistics (CBS). This data set contains information on the (changes in) the housing situation in individual households in the period 1978-1981 and on household characteristics at the time of the interview, which took place at the end of this period. From this file we sub-sampled the 22,500 households in the reduction stage. There are many definitions of the concept of household life cycle, differentiating two to 24 stages in the total span of adult life (Duvall 1977). If only two stages are distinguished, the reduction stage is the period from the moment the first child leaves the parental home until the moment the household dissolves, which can happen when the last partner dies, moves in with one of the children, or is admitted to an institution. This lengthy reduction stage can be differentiated into child-launching, emptynest and widowhood phases (Abu-Lughod \& Foley 1960). The concept of family life cycle has encountered severe criticism over the last decade (Trost 1977, Stapleton 1980). It has been pointed out that, due to rising divorce rates and the increased tendency to remain single or childless, a large number of households do not fit into these categories. Although it has been established that less than $5 \%$ of the women aged 45 or over in the Netherlands have never been married and that more than $85 \%$ have had at least one child (Hooimeijer \& Linde 1987), rendering the traditional life cycle concept less obsolete than might have been expected, we have nevertheless chosen a very flexible definition of our research popu- 
lation. Hence households in the reduction stage are operationally defined as those households having a female head of 47 years or older. The cut-off point of 47 years is based on the average age of the mother when the first child leaves the parental home (Hooimeijer et al. 1986). The female was designated head of the household in our definition, because the age of children is more closely related to the age of the mother than to the age of the father. Within this broad definition of the reduction stage, we allowed for three to six household positions and a classification into four-year or eight-year intervals (Table 1).

Residential mobility has been defined as moves between independent dwellings within the confines of a housing market area, which in turn is defined as the area within which people can relocate without loss of social and cultural contacts or necessitating a change in workplace. In the wBo81, Dutch municipalities are classified into 51 housing market areas (cf. Deurloo 1987). This definition of mobility covers more than $80 \%$ of all moves made by households in the reduction stage, as Table 2 shows. The reason for the small share of longdistance migration among this group is the relative absence of retirement migration in the Netherlands (Vergoossen \& Warnes 1987). Unlike countries such as the United States or Great Britain, the Netherlands does not have regions which are particularly attractive for the retired.

Eight different types of dwelling were distinguished to define housing choice (Table 3). The typology is based on earlier research (Hooimeijer \& Dieleman 1986) which revealed tenure class, type of structure and size of the dwelling to be the most important dimensions of housing choice among households in the reduction stage. Other characteristics of dwellings, like price or rent, partly coincide with these dimensions. The option move/no move and the choice of one of the eight types of dwellings are used as the dependent variables in the analyses reported in this article.

The initial choice set of independent variables refers to three different sets of factors influencing mobility and choice (Table 1).

- The first group comprises household characteristics such as household composition, age of the head, income and participation in the labour force.

- The second group encompasses relevant attributes of the present or prior dwelling such as tenure class, size, type, period of con- struction and number of persons per room.

- The third group pertains to the spatial context within which the move is made, indicating variations in the supply of dwellings and the composition of the housing stock. This spatial context has a noticeable influence on both mobility rates and choice patterns in general (cf. Deurloo 1987). At the regional level a distinction has been made between the Randstad and the rest of the Netherlands, because supply of housing and composition of the stock vary most markedly between these two parts of the country. The mobility also varies with the degree of urbanization of the housing market, a local aspect of housing market context. The size of the municipality by number of inhabitants was used as an indicator for urbanization.

The categorisation of each of the independent variables (Table 1) has been made as detailed as the original data set would allow. Age and income form an exception; for these variables, the categorisation has been simplified to make the analyses more manageable with the techniques we used.

\section{Techniques of analysis}

In the analysis of residential mobility and housing choice it is often necessary to rely on data sets such as wBo81 which contain many categorical independent and/or dependent variables. Logit analysis is often an appropriate tool to model the relationship between such variables (Wrigley 1985). But given a data set with a large number of variables which may be supposed to have a relationship with mobility and choice, direct application of logit analysis to the data is often problematic or impossible, especially if the variables have a large number of categories. A cross tabulation of the variables in Table 1, for example, would yield so many cells that zeros or small numbers of observations would occur in many cells. The estimates of parameters of a logit model for such a table would be unreliable and the many parameters of the model would escape meaningful interpretation.

In such situations a thorough pre-processing of the data prior to logit analysis is necessary, as many researches have argued (e.g. Higgins \& Koch 1977, Green 1978, Magidson 1982). The pre-processing involves selection of the most relevant independent variables from a larger set and simplification of the categorisation of these variables. A two- or three-stage 
Table 1. Categorisation of independent variables.

\begin{tabular}{lll}
\hline Variable & Categories:mobility analysis & Categories: housing choice analysis \\
\hline Household composition & 1. Single & 1. Single \\
& 2. Two-person unmarried & 2. Couple \\
& 3. Two-person married & 3. Family \\
& 4. Two-parent family & \\
5. One-parent family & \\
6. Multi-family household & \\
Age oldest child & 1. $0-7$ & \\
& 2. $8-11$ & \\
a. 36 or older & \\
10. No children
\end{tabular}

Age youngest child

Labour-force participation

Net household income

Age, female head of household

(Previous) tenure

(Previous) \# of rooms

(Previous) type of dwelling

(Previous) period of construction
1. $0-7$

2. $8-11$

...

9. 36 or older

10. No children
1. Single, no job
2. Single with job
1. No
2. Yes

3. Multi-person h.h., no job

4. Multi-person h.h., one job

5. Multi-person h.h., two jobs
1. $0-14,000 /$ year
2. $14-17,000$
3. $17-20,000$
4. $20-23,000$
5. $23-26,000$
6. $26-30,000$
7. $30-34,000$
8. $34-42,000$
9. $42-50,000$
10. 50,000 and more
99. Missing values
1. $47-50$
2. $51-54$
9. $79-82$
10. $83+$
1. Private rental
2. Public rental
3. Owner-occupier
9. Missing values

1. 3 or less

2. 4

3. 5 or more

9. Missing values

1. Single-family

2. Multi-family

1. 1905 or before

2. 1906-1944

3. $1945-1969$

4. 1970 or later

9. Missing values

idem
1. $0-14,000 /$ year

2. $14-23,000$

3. $23-30,000$

4. $30-42,000$

5. 42,000 and more

99. Missing values
1. $47-54$
2. $55-62$
3. $63-70$
4. $71-78$
5. $79+$
1. Rental
2. Owner-occupier
9. Missing values

idem 
Table 1. (Continued).

\begin{tabular}{|c|c|c|}
\hline Variable & Categories: mobility analysis & Categories: housing choice analysis \\
\hline \# Rooms per person & $\begin{array}{ll}\text { 1. } & 0 \quad-0.24 \\
\text { 2. } & 0.25-0.49 \\
\text { 3. } & 0.50-0.74 \\
\text { 4. } & 0.75-0.99 \\
\text { 5. } & 1.00-1.24 \\
\text { 6. } & 1.25-1.49 \\
\text { 7. } & 1.50 \text { or more }\end{array}$ & $\begin{array}{ll}\text { 1. } & 0 \quad-0.24 \\
\text { 2. } & 0.25-0.49 \\
\text { 3. } & 0.50-0.74 \\
\text { 4. } & 0.75 \text { or more }\end{array}$ \\
\hline Size municipality & $\begin{array}{l}\text { 1. }<5,000 \text { inhabitants } \\
\text { 2. } 5-10,000 \\
\text { 3. } 10-20,000 \\
\text { 4. } 20-50,000 \\
\text { 5. } 50-100,000 \\
\text { 6. } 100,000 \text { or more }\end{array}$ & $\begin{array}{l}\text { 1. }<10,000 \\
\text { 2. } 10-20,000 \\
\text { 3. } 20-50,000 \\
\text { 4. } 50-100,000 \\
\text { 5. } 100,000 \text { or more }\end{array}$ \\
\hline Location housing market & $\begin{array}{l}\text { 1. Randstad } \\
\text { 2. Rest of the Netherlands }\end{array}$ & idem \\
\hline
\end{tabular}

modelling strategy, employing different techniques, was proposed recently by Clark et al. (1988). We used (some of) the techniques they recommended. We summarize the characteristics and purpose of the techniques here briefly; readers should refer to Deurloo (1987) and Clark et al. (1988) for a more detailed discussion.

Two techniques were used here for pre- processing the data, viz. Proportional Reduction of Uncertainty (PRU) and - to a lesser extent - Chi-square Automatic Interaction Detection (CHAID) (Teachman 1980, Kass 1980). Given the dependent variable (move/no move or housing choice), the PRU criterion selects the independent variables that are most relevant in a sequential manner. The variable which explains most of the distribution of the

Table 2. Mobility of households in the reduction stage, 1978-1981.

\begin{tabular}{llllr}
\hline Household type & Non-movers $(\%)$ & $\begin{array}{l}\text { Movers within housing } \\
\text { market area }(\%)\end{array}$ & $\begin{array}{l}\text { Movers across housing } \\
\text { market areas }(\%)\end{array}$ & $\begin{array}{c}\text { Total } \\
\text { Single }\end{array}$ \\
Couple & 88.0 & 10.2 & 1.8 & 100.0 \\
Family & 88.1 & 9.7 & 2.2 & 100.0 \\
Total & 90.8 & 7.9 & 1.3 & 100.0 \\
\hline
\end{tabular}

Source: wBo81.

Table 3. The housing typology in 1981 (number $\times 1000$ ).

\begin{tabular}{lrr}
\hline Type of dwelling & Number & Percentage \\
\hline Rental, multi-family, 3 rooms or less & 776,7 & 15.8 \\
Rental, multi-family, 4 rooms or more & 602,5 & 12.2 \\
Rental, single-family, 3 rooms or less & 247,0 & 5.0 \\
Rental, single-family, 4 rooms & 710,1 & 14.4 \\
Rental, single-family, 5 rooms or more & 527,0 & 10.7 \\
Owner-occupier, 3 rooms or less & 273,4 & 5.5 \\
Owner-occupier, 4 rooms & 735,5 & 14.9 \\
Owner-occupier, 5 rooms or more & 1053,9 & 21.3 \\
Total & 4926,2 & 100.0 \\
\hline
\end{tabular}

Source: wBo81. 
observations over the categories of the dependent variable is chosen first; categorisation is simplified using the same PRU criterion, which is based on the change in entropy in the dependent variable. Variables are added until no relevant additional variables can be included or until the data are exhausted. The analyses with the PRU criterion are reported most extensively in this article because it is a more appropriate method of pre-processing than CHAID if one uses un-nested logit models as we have done here (Clark et al. 1988).

CHAID has the same purpose as the PRU method and also employs a forward stepwise procedure, though with a different theoretical underpinning than PRU. CHAID stems from the automatic interaction detection of Sonquist \& Morgan (1964). The major difference between CHAID and the PRU criterion is that CHAID permits the nesting of independent variables within categories of other independent variables. Both methods yield a selection of independent variables that are usually not strongly interrelated: in addition, they generally allow a simplification of the categorisation of variables without important loss of information. In this article, CHAID is only used to verify if the selection of independent variables and the simplification of categories is not too dependent on the PRU procedure. The results of CHAID are therefore not reported extensively.

The simplified cross tabulations resulting from pre-processing can often be successfully analysed with logit models. Clark et al. (1988) point out that it is sometimes practical to use a simplified form of logit modelling known as Multivariate Nominal Scale Analysis (MNA, cf. Andrews \& Messenger 1973) or ANalysis Of TAbles (ANOTA, Keller \& Verbeek 1984). MNA/ANOTA makes the restricting assumption that an additive model adequately represents the data. This assumption facilitates the computation and interpretation dramatically, as compared to logit analysis. The results of the analysis with ANOTA indeed allow straightforward interpretation and are comparable to the results of a multiple regression analysis. It is especially useful to apply this technique if the dependent variable and (some of) the independent variables have more than two categories. We will use this technique in our analysis of housing choice.

Because the techniques are adequately described and illustrated in the literature and because the results are easy to understand, these brief remarks will suffice here. We will give further explanation when necessary along with the presentation of the results.

\section{The propensity to move}

The relationship between the dependent variable, move/no move, in the period 1978-1981 for households in the reduction stage, and the independent variables that characterize these households and their housing conditions was first analysed with the PRU criterion. Table 4, step la, shows all the independent variables that have an effect on move/no move at the one-percent significance level. All the PRU values are low because the overall mobility rate of the research population is only $9.3 \%$ over the four years.

Tenure class is the best predictor of the propensity to move. Households in the reduction stage that own their house are less likely to move than renters. The quality of the dwelling (indicated by the period of construction) and the characteristics of the housing market also have a strong effect on the propensity to move; the older the house and the larger the municipality, the more likely one is to move. The number of rooms per person is also related to mobility. Older households tend to move away from excess space; the more rooms per person they have, the more likely they are to move. These relationships are logical and comply with the general literature on mobility (Clark et al. 1986). But it is striking that age of the head of household and other indicators of the life cycle stage are relatively unimportant as predictors of mobility. In analysing the propensity to move of the total number of households in the Netherlands, we found that age is always overwhelmingly the most important predictor of move/no move (Deurloo 1987).

In the stepwise procedure using the PRU criterion to select important independent variables from a wider set, the variable with the highest value is selected in the first step (tenure, in this case). The criterion indicates that the categorisation of previous tenure can be simplified without significant loss of information; mobility does not differ much between renters in the private (1) or public (2) sectors and therefore these categories are joined in step 1b. Step la leads to the cross tabulation of move/no move by tenure. In step $2 \mathrm{a}$, all the other independent variables are considered for addition to this two-by-two table. Only four predictors have PRU values that are significant 
Table 4. Steps in the selection procedure using the PRU criterion (dependent variable: move/no move).

\begin{tabular}{|c|c|c|}
\hline & Independent variable & PRU \\
\hline \multirow[t]{13}{*}{ Step la } & Previous tenure $(1,2,3)$ & 0.00652 \\
\hline & Previous period of construction & 0.00541 \\
\hline & Municipality size & 0.00529 \\
\hline & \# of rooms per person & 0.00449 \\
\hline & Previous type of dwelling & 0.00420 \\
\hline & Household composition & 0.00409 \\
\hline & Labour-force participation & 0.00314 \\
\hline & Age oldest child & 0.00285 \\
\hline & Age head of household & 0.00218 \\
\hline & Age youngest child & 0.00167 \\
\hline & Net income & 0.00143 \\
\hline & Location of housing market & 0.00040 \\
\hline & Previous \# of rooms & 0.00037 \\
\hline Step $1 b$ & Previous tenure $(1+2,3)$ & 0.00612 \\
\hline \multirow[t]{4}{*}{ Step $2 \mathrm{a}$} & Prev. ten. * previous period of construction $(1,2,3,4)$ & 0.01403 \\
\hline & Prev. ten. $* \#$ rooms per person & 0.01223 \\
\hline & Prev. ten. * household composition & 0.01113 \\
\hline & Prev. ten. * age head of household & 0.01096 \\
\hline \multirow[t]{2}{*}{ Step $2 b$} & Prev. ten. * previous period of construction $(1+2,3,4)$ & 0.01375 \\
\hline & Prev. ten. * previous period of construction $(1+2,3+4)$ & 0.01331 \\
\hline \multirow[t]{2}{*}{ Step $3 \mathrm{a}$} & Prev. ten. * prev. period constr. * age head of hshld. $(1,2,3,4,5,6,7,8,9,10)$ & 0.02117 \\
\hline & Prev. ten. * prev. period constr. *\# rooms per person & 0.01944 \\
\hline \multirow[t]{3}{*}{ Step $3 b$} & Prev. ten. $*$ prev, period constr. $*$ age head of hshld. $(1+2+3+4,5+6+7+8,9,10)$ & 0.01917 \\
\hline & Prev. ten. * prev, period constr. * age head of hshld. $(1+2+3+4+5+6+7+8,9,10)$ & 0.01817 \\
\hline & Prev. ten. * prev. period constr. * age head of hshld. $(1+2+3+4,5+6+7+8,9+10)$ & 0.01747 \\
\hline
\end{tabular}

at the one-percent level. The effect of size of municipality, apparent in step 1, plays no further role because tenure varies strongly between municipalities of different sizes. The addition of this variable to the table, therefore, does not help to distinguish further between move/no move. The age of the dwelling and characteristics of the households remain important predictors of the propensity to move after the effect of tenure has been accounted for. Period of construction is added to the cross tabulation in step $2 \mathrm{a}$ and can be reduced to a distinction between pre- and postwar housing in step $2 \mathrm{~b}$. In step 3 only the age of the head of household and the number of rooms per person lead to a significant increase in the explained variation of mobility. Age is selected and reduced to three categories in step 3 b, viz. 47-62 years, 63-78 years and 79 years and older. None of the other variables could be successfully added to the, by now, fourdimensional cross tabulation in step 4 .

The cross tabulation of mobility by tenure and period of construction of the (previous) dwelling and by age of the head of the household is presented graphically in Figure 1. This figure shows that the propensity to move varies considerably and fairly systematically over the categories of the three predictors that have been chosen with the PRU criterion. The effects of tenure and period of construction of the (previous) dwelling on the mobility rate show up very clearly. In the rental sector and in older housing the propensity to move is relatively high. Age has a fairly regular effect on the propensity to move within the categories of the other two independent variables. The very old move least, and those 63 to 78 years old move more frequently, although of course the mobility rate of all households in the reduction stage is low in comparison with young, growing households. The somewhat higher mobility rate between the ages of 63 and 78 is probably related to changes that are likely to occur in the situation of the household in that period of the life cycle, like death of one of the partners, retirement and related changes like a decrease in income and a decline in health. But tenure and quality of housing are more important than age as predictors of mobility of the older households, a fact hardly encountered in the literature. 

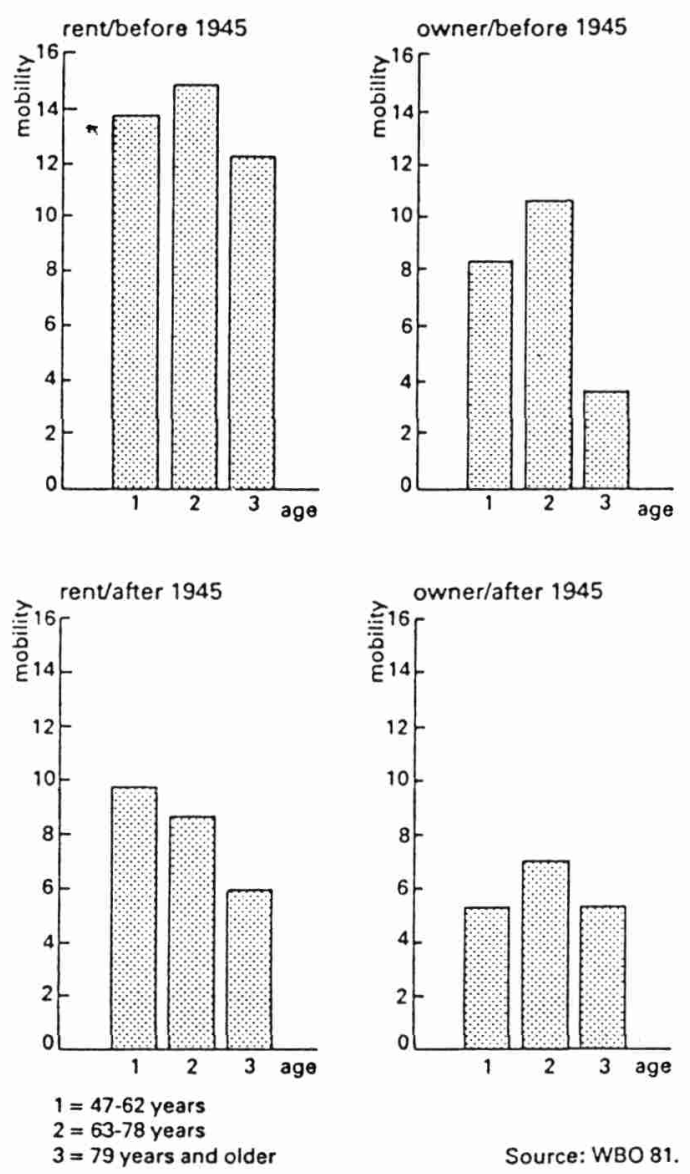

Fig. 1. Percentage of households that moved, 1978-1981, by tenure and period of construction of (previous) dwelling and by age of head of household.

The pre-processing of the same data with CHAID substantiates the findings of PRU (Fig. 2 ). Tenure is again the most important determinant of the decision to move/not move among households in the reduction stage. But for homeowners, household composition is indicated as the second most important independent variable. Families with children in the reduction stage show a lower propensity to move in this sector than other households. Quality of housing (period of construction) enters the model as a third variable in this tenure class, but remains in second place in the rental sector. Therefore, household composition is added to the set of independent variables that were chosen in the PRU procedure and entered into the more formal logit analysis of mobility and factors influencing mobility, which is described in the next section.

The analysis with PRU and CHAID help to select the most important factors that influence move/no move from a much wider set of independent variables that are related to mobility. Still, it can be useful to proceed with more formal modelling to determine how interaction effects between independent variables affect mobility and to simplify the models by deleting unimportant effects from the models. Table 5 shows the results of a standard logit analysis (Wrigley 1985) between mobility and the four independent variables that were revealed to be important by the pre-processing analyses with PRU and CHAID, viz. Tenure, Period of construction, $A$ ge and Household composition.

Starting with the saturated model, including all interaction effects, a backward hierarchical selection procedure was used to eliminate those effects that are not significant at the one-percent level. The interaction effects of the independent variables on mobility that include period of construction (P) can all be removed from the model, until only the main effect of this variable on mobility remains. Partitioning of the likelihood-ratio shows that a satisfactory model can be constructed which includes the main effect of period of construction and the second-order integration effect of tenure, age and household composition. In step 7, the term $\mathrm{A} * \mathrm{P}$ can still be removed; the likelihood-ratio value is 29.35 after this step out of a maximum of 272.93 , so almost $90 \%$ of the total variation is explained by this parsimonious model. The model has only 13 parameters (age of the head of household had three categories, all other variables have two categories).

The results of the logit analysis seem to indicate that quality of housing has an independent effect on the propensity to move of households in the reduction stage. Low quality of housing leads to a higher mobility rate, regardless of the other factors influencing mobility. Age, household composition, and tenure show interaction effects on the propensity to move.

\section{Housing choice}

In this section we analyse the housing choice of households that moved in the period 19781981. Of course many households in the reduction stage did not move during this period, and therefore the number of observations is smaller than in the analysis of mobility in the previous section. The number of categories of 


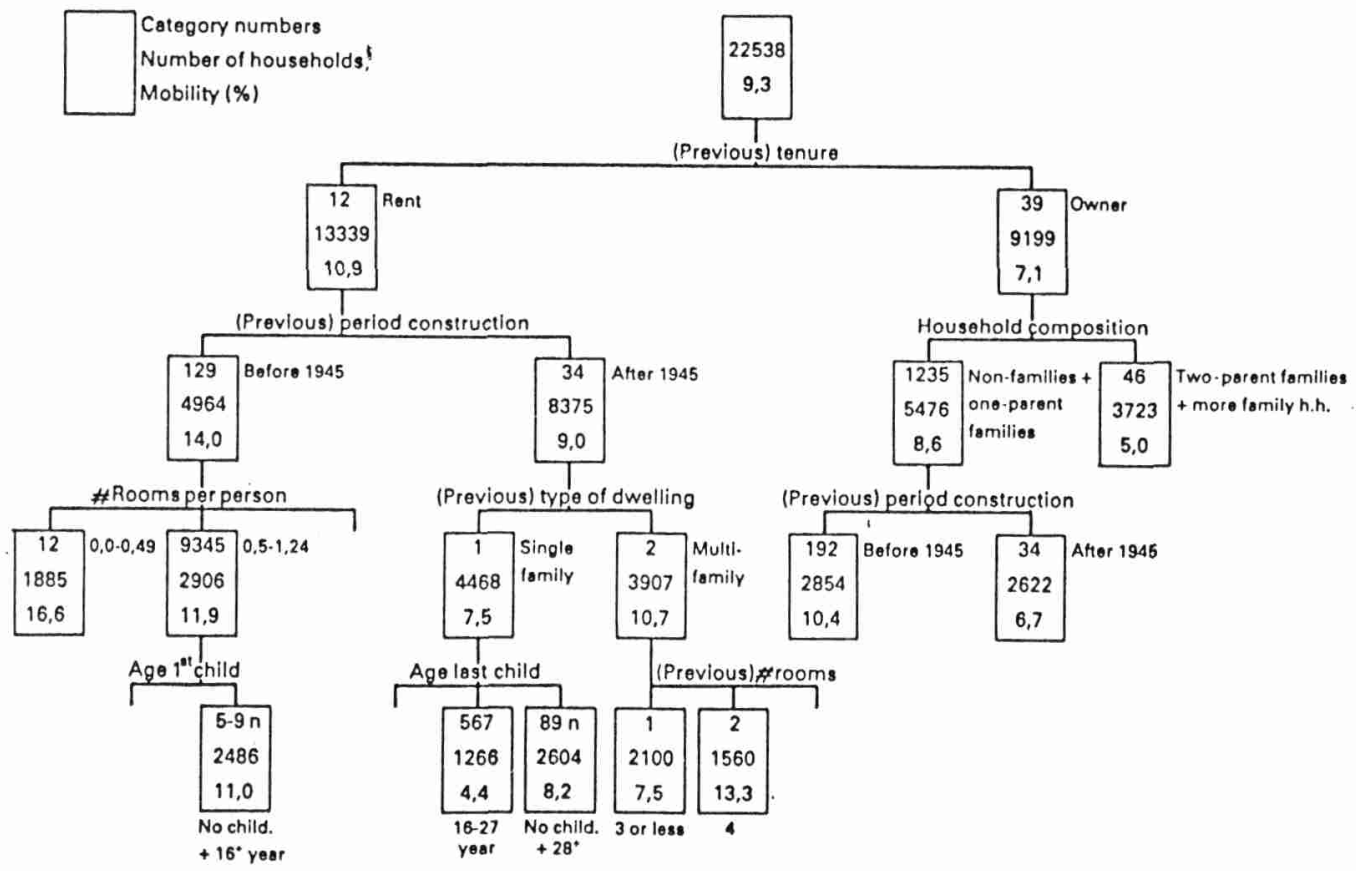

Fig. 2. CHAID dendogram of percentage of households that moved.

the independent variables we used is now smaller, because categories with only a few observations were added to larger categories (see Table 1). Housing choice (Table 3) is the dependent variable, but the set of independent variables is the same as in the analysis of mobility described above.

The exploratory procedure with the PRU criterion shows a strong effect of household composition on choice (Table 6). Tenure of previous dwelling, age of the head of household, and municipality size are also strongly related to choice. It is interesting to note the relatively small effect of income on choice. For all the households in the Netherlands, income is by far the most important determinant of

Table 5. Complete backward logit regression of move/no move, with age head of household ( $A$ ), household composition $(H)$, period of construction $(P)$, and tenure $(T)$.

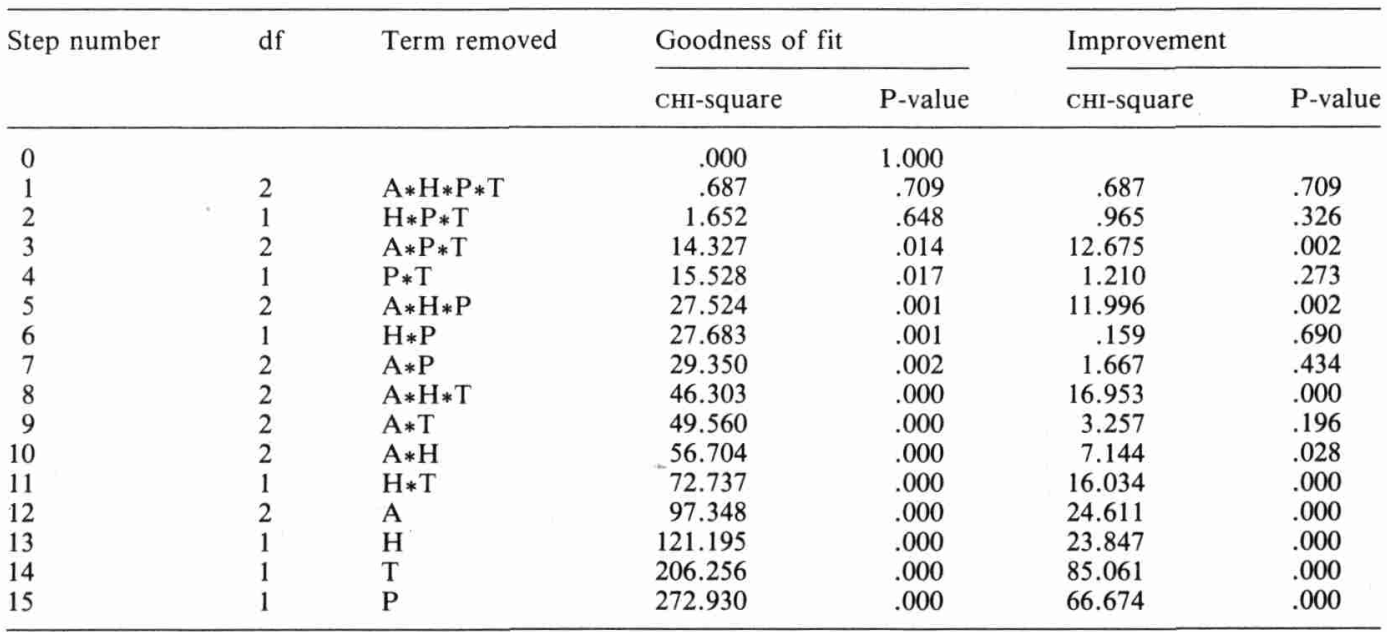


Table 6. Steps in the selection procedure using the PRU criterion (dependent variable: housing choice).

\begin{tabular}{llr}
\hline & Independent variable & PRU \\
\hline Step 1a & Household composition $(1,2,3)$ & 0.1050 \\
& Previous tenure & 0.0737 \\
Age head of household & 0.0671 \\
& Municipality size & 0.0578 \\
& Net income & 0.0467 \\
Previous \# of rooms & 0.0402 \\
\# rooms per person & 0.0395 \\
Location of housing market & 0.0364 \\
Previous type of dwelling & 0.0347 \\
Labour-force participation & 0.0096 \\
\hline
\end{tabular}

Step $1 \mathrm{~b}$

Step $2 \mathrm{a}$

Hshld. comp. * previous tenure

0.1793

Hshld. comp. * municipality size

0.1709

Hshld. comp. * net income

0.1544

Step $2 b$

Step 3a

Hshld. comp. * prev. ten. * municipality size

0.2434

Hshld. comp. * prev. ten. * net income

0.2419

Step $3 b$

dwelling choice (Deurloo et al. 1987). But for older households, income seems to play only a minor role, and housing choice is influenced more by the composition of the household.

In step la we selected the composition of the household as the first variable for cross tabulation with housing choice. The categorisation of this variable could not be simplified without significantly reducing the PRU value in step 1b. Tenure of the previous dwelling, municipality size, and income also determine choice after the effect of household composition has been accounted for (Table 6). Previous tenure and municipality size are selected in steps 2 and 3 of the PRU procedure. The categorisation of these variables cannot be simplified further. Income has only a slightly lower PRU value than municipality size in step 3 , but it cannot be added in a subsequent step 4 (the data are then exhausted and too many empty cells occur). The results of the PRU preprocessing are corroborated by a CHAID analysis we also performed on the same data. The interpretation of these results follows in the next paragraph, where the choice patterns of households over the categories of the independent variables are described in greater detail.

To construct a more formal model of the housing choice of older households, we decided to use the additive ANOTA model (see the section on techniques). We could have used a mul- tinomial logit analysis as well. But with so many categories of dependent and independent variables, a multinomial logit analysis soon becomes counter-productive, because the analysis is complicated and the results are difficult to interpret. In our experience, the assumption that an additive model can be used to represent the data makes it a good alternative strategy to logit modelling (see Clark et al. 1988). In the ANOTA method, which uses this assumption, estimated coefficients show the effect of being in a particular category of an independent variable on the likelihood of selecting a particular category of the dependent variable. The coefficients are corrected for the influence of other independent variables and can therefore be treated as partial regression coefficients, as in multiple regression of interval- and ratio-scale variables. For a detailed description, see Deurloo et al. (1987).

The three independent variables selected in the analysis with the PRU criterion were subsequently entered into the ANOTA procedure. The cross tabulation of these three variables with housing choice shows that first-time buyers are virtually non-existent among households in the reduction stage of the life cycle. Nearly every household with a previous dwelling in the rental sector remains in that sector of the housing market. The table also shows that tenure and size of municipality are closely inter- 
related, as we noted already in the analysis of move/no move (Table 4). These circumstances lead to empty cells in the table, and the interrelationship between tenure and municipality clearly violates the assumptions of ANOTA. The ANOTA analysis was therefore carried out separately for (former) owners and renters.

The results of the analysis are shown in Table 7. The coefficients are simple to interpret. They can be added to or subtracted from the average to elucidate the influence on choice of being in a particular category of an independent variable. For instance, of the elderly households that owned their former dwelling and (now) live in a settlement with less than 20,000 inhabitants, $73.6 \%(48.0+19.7+5.9)$ moved into single-family owner-occupier housing. Among the owner-occupiers who live alone and moved within or into a city of over 100,000 inhabitants, $40.8 \%(16.1+17.1+7.6)$ chose a small apartment in a multi-family structure. This percentage rises to 73.7 $(38.4+23.4+11.9)$ in cases where they rented their former dwelling and (now) occupy a house in a city of over 100,000 inhabitants. These figures illustrate that tenure, household composition, and size of the municipality have a strong impact on the housing choice of older households that move.

On the whole, the patterns of choice demonstrated by households in different categories of the independent variables are fairly obvious and easy to interpret. Renters remain in rental accommodation; no more than $20 \%$ of the renters move to owner-occupation. The smaller the household, the more it tends to move into a small dwelling or into multifamily housing. The larger the municipality, in terms of inhabitants, the more renters move into multi-family housing. Owners move into rental accommodation more often than renters buy a house. Especially single persons move away from owner-occupation housing $(70 \%)$. Families tend to remain in the owneroccupied sector. Former owner-occupiers are more likely to choose large, single-family dwellings if they move into the rental sector than movers who were already in this sector. Apparently they are used to more space and therefore move into more spacious accommodation. The choice for single- or multi-family housing is determined to a large extent by the size of the municipality households move in (to). The larger the municipality, the more households (have to) move into the multifamily housing that forms a considerable part of the housing stock in cities.

\section{Conclusions}

The most important conclusion of this research is that socio-economic variables do not play a major role in the short-distance relocation behaviour of households in the reduction stage in the Netherlands. Neither in-

Table 7. ANOTA coefficients for housing choice by (previous) tenure, household composition and municipality size.

Ownership

\begin{tabular}{|c|c|c|c|c|c|c|c|c|}
\hline \multirow[t]{2}{*}{ Type of dwelling } & \multirow[t]{2}{*}{ Average } & \multicolumn{3}{|c|}{ Household composition } & \multicolumn{4}{|c|}{ Municipality size $(\times 1000)$} \\
\hline & & Single & Couple & Family & 20 or less & $20-50$ & $50-100$ & 100 or more \\
\hline Rent, single, small & 10.9 & 8 & 0.8 & -8.4 & 13.3 & 1.2 & -2.4 & -7.4 \\
\hline Rent, multi, small & 16.1 & 17.1 & 0.2 & -12.4 & -8.5 & -4.0 & 1.0 & 7.6 \\
\hline Rent, single, large & 10.1 & -5.1 & -0.9 & 4.4 & 1.2 & 1.6 & -1.6 & -0.4 \\
\hline Rent, multi, large & 4.5 & -2.9 & 1.0 & 1.0 & -2.6 & -2.9 & 1.1 & 2.8 \\
\hline Owner, single & 48.0 & -29.2 & 0.8 & 19.7 & 5.9 & 8.5 & 0.5 & -10.7 \\
\hline Owner, multi & 10.5 & 9.3 & -2.0 & -4.5 & -9.3 & -4.4 & 1.3 & 8.2 \\
\hline
\end{tabular}

\section{Rental}

\begin{tabular}{|c|c|c|c|c|c|c|c|c|}
\hline \multirow[t]{2}{*}{ Type of dwelling } & \multirow[t]{2}{*}{ Average } & \multicolumn{3}{|c|}{ Household composition } & \multicolumn{4}{|c|}{ Municipality size $(\times 1000)$} \\
\hline & & Single & Couple & Family & 20 or less & $20-50$ & $50-100$ & 100 or more \\
\hline Rent, single, small & 16.0 & 5.4 & 2.3 & -8.2 & 11.6 & 0.7 & 3.8 & -7.3 \\
\hline Rent, multi, small & 38.4 & 23.4 & 2.9 & -27.6 & -16.8 & -8.9 & 2.0 & 11.9 \\
\hline Rent, single, large & 21.7 & -15.7 & -2.8 & 19.4 & 12.7 & 6.1 & -1.8 & -8.5 \\
\hline Rent, multi, large & 14.5 & -9.0 & -1.1 & 10.6 & -10.8 & -1.5 & -0.7 & 6.0 \\
\hline Owner, single & 7.5 & -4.5 & -0.7 & 5.4 & 5.0 & 3.6 & -3.2 & -3.0 \\
\hline Owner, multi & 1.8 & 0.4 & -0.7 & 0.4 & -1.1 & -0.3 & -0.1 & 0.7 \\
\hline
\end{tabular}


come nor retreat from the labour force are significant predictors of the level of mobility and of housing choice of this group of households. Income differentials do show up if participation in longer-distance migration is analysed (Barink \& Hooimeijer 1988). However, as we have shown, $80 \%$ of all moves made by households in the reduction stage can be classified as intra-urban. On the basis of career life cycle model of residential mobility (Leslie \& Richardson 1966), it might be expected that higher-income groups have a greater mobility even in older age because they have a more prolonged housing career. And income certainly plays a dominant role in the housing choice of all the households in the Netherlands, in the rental as well as in the owneroccupier sector (Deurloo et al. 1987). Even the strongly regulated nature of the Dutch housing market cannot alter this influence of income on housing choice. But for older households, we were not able to demonstrate a relationship between income and choice. The results of the present study seem to corroborate earlier findings (Hooimeijer et al. 1986) that the housing career of households is mainly determined before the age of 45 , hence before the reduction stage, according to our definition. From then on, demographic characteristics of the households and the past housing career seem to be more important for housing choice than income.

The quality of the housing, represented by period of construction in this analysis, is seldom taken into account in empirical studies of filtering and mobility. Apparently the state of repair and the presence or absence of modern facilities like central heating, elevators etc. have an influence on a household's decision whether to adjust their housing situation or to remain in the dwelling they occupy. Households in the reduction stage who live in older buildings are more likely to change their housing situation than households in more recent and modern structures. The fifteen years from the age of 63 to the age of 78 define the period when the generally low mobility of households in the reduction stage becomes somewhat higher. Probably the death of a partner in a two-person household or a state of deteriorat-

\section{References:}

Abu-Lughod, J. \& M. M. FOLEY (1960), The Consumer Votes by Moving. In: N. N. Foote, J. ABU-LughoD, M. M. FoleY \& L. WINNICK, eds., Housing Choices and Housing Constraints. New York: McGraw Hill. ing health make an adjustment move more likely at this time of life.

In our analysis, household composition proves to be the main determinant of housing choice of households in the reduction stage that make an adjustment move. Single persons predominantly go to small housing in the rental sector. The two- or three-person households in the reduction stage that do move tend to make housing choices that resemble the choices of younger households. They remain more often in the owner-occupied sector and in single family housing that is comparatively large.

Again, the characteristics of the housing market one lives in or moves to, and especially the composition of the housing stock in that market, influence and constrain choice. This fact was demonstrated earlier for all the households in the Netherlands (Deurloo 1987) and it also applies to older households that move. Households that live in or move to more urbanized areas will (have to) choose multifamily housing more often than those living in more rural surroundings. Especially in the Randstad, the housing stock is predominantly multi-family housing; single-family homes are hard to obtain in this part of the country, and households will not always be able to move into such housing even if they have a preference for it. The ageing of the population will therefore lead to other filtering processes. The demand for small, rental housing will increase. Spacious and owner-occupier dwellings will be in less demand as a result of the moves to these small dwellings.

With respect to the techniques applied in the analysis, we may conclude again that the combination of exploratory analysis with more formal modelling leads to clear and parsimonious results (Deurloo et al. 1987). The exploratory procedures filter the most important relationships from a much wider set and help to reduce redundancy in the categorisation of the variables. When the small set of most relevant independent variables is selected in the preliminary analysis, it is then possible to construct fairly simple formal models of the relationships.

ANDREws, F. M. \& R. C. Messenger (1973), Multivariate Nominal Scale Analysis. Ann Arbor: Institute for Social Research, University of Michigan.

BARINK, J. \& P. HoOIMEIJER (1988), De migratie van oude- 
ren in de tijd. Stedelijke Netwerken, Werkstukken 4. Zoetermeer : Ministerie van Onderwijs en Wetenschappen.

CLARK, W. A. V. (1986), Modeling Mobility: Theoretical Contributions Versus Policy Relevancy. Tijdschrift voor Economische en Sociale Geografie 77, pp. 358-367.

Clark, W. A. V., M. C. Deurloo \& F. M. Dieleman (1986), Residential Mobility in Dutch Housing Markets. Environment and Planning $A$ 18, pp. 763-788.

Clark, W. A. V., M. C. Deurloo \& F. M. Dieleman (1988), Modeling Strategies for Categorical Data: Examples from Housing and Tenure Choice. Geographical Analysis 20, pp. 197-217.

Deurloo, M. C. (1987), A Multivariate Analysis of Residential Mobility. Amsterdam: Instituut voor Sociale Geografie, Universiteit van Amsterdam.

Deurloo, M. C., F. M. Dieleman \& W. A. V. Clark (1987), Tenure Choice in the Dutch Housing Market. Environment and Planning A 19, pp. 763-781.

Duvall, E. (1977), Family Development. Philadelphia: Lippincott.

Golant, S. M. (1984), The Geographical Literature of Ageing and Old Age : An Introduction. Urban Geography 5, pp. 262-272.

Green, (1978), An AID/Logit Procedure for Analyzing Large Multiway Contigency Tables. Journal of Marketing Research 15, pp. 132-136.

Higgins, J. W. \& G. G. КосH (1977), Variable Selection and Generalized Chi-square Analysis of Categorical Data Applied to a Large Cross-sectional Occupational Health Survey. International Statistical Review 45, pp. 51-62.

Hoormeijer, P. \& F. M. Dieleman (1986), Huishoudens in de reductiefase en woonruimteverdeling. 'sGravenhage: Ministerie van Volkshuisvesting, Ruimtelijke Ordening en Milieubeheer.

Hooimeijer, P. \& M. A. J. Linde (1987), Demographic Change, Household Evolution and Housing Needs. Utrecht: Department of Geography, University of Utrecht.

Hoomejer, P., W. A. V. Clark \& F. M. Dieleman (1986),
Households in the Reduction Stage: Implications for the Netherlands Housing Market. Housing Studies 1, pp. 195-209.

Hooimener, P., F. M. Dieleman \& J. van Dam (1987), Huishoudens in de reductiefase op de woningmarkt, Analyse van gedrag en vooruitblik naar het jaar 2000 . Tijdschrift voor Gerontologie en Geriatrie 18, pp. 233-239.

KASs, G. V. (1980), An Exploratory Technique for Investigating Large Quantities of Categorical Data. Applied Statistics 29, pp. 119-127.

Keller, W. J. \& A. Verbeek (1984), ANota: Analysis of Tables. Kwantitatieve Methoden 15, pp. 1-16.

Kendig, H. L. (1984), Housing Careers, Life Cycle and Residential Mobility: Implications for the Housing Market. Urban Studies 21, pp. 271-283.

Leslie, G. R. \& A. H. Richardson (1966), Life Cycle, Career Pattern and the Decision to Move. American Sociological Review 26, pp. 147-159.

Magidson, J. (1982), Some Common Pitfalls in Causal Analysis of Categorical Data. Journal of Marketing Research 19, pp. 461-471.

Sonquist, J. A. \& J. N. Morgan (1964), The Detection of Interaction Effects. Ann Arbor: University of Michigan.

Stapleton, C. (1980), Reformulation of the Family Life Cycle Concept. Environment and Planning $A 12$, pp. $1103-1118$

Teachman, J. D. (1980), Analysis of Population Diversity, Measures of Qualitative Variation. Sociological Methods and Research 8, pp. 341-362.

Trost, F. (1977), The Family Life Cycle: A Problematic Concept. In: F. Cuisinier, ed., The Family Life Cycle in European Societies, pp. 467-482. The Hague/Paris: Mouton.

Vergoossen, Th. W. M. \& A. M. WARnes (1987), Mobility of the Elderly. Paper presented at Conference on Comparative Population Geography of the United Kingdom and of the Netherlands, Oxford.

Wrigley, N. (1985), Categorical Data Analysis for Geographers and Environmental Scientists. London: Longman. 


\section{THE NETHERLANDS IN MAPS}

Regional potential for distribution and information and number of firms in the information technology sector, by COROP area, 1.1.1986.

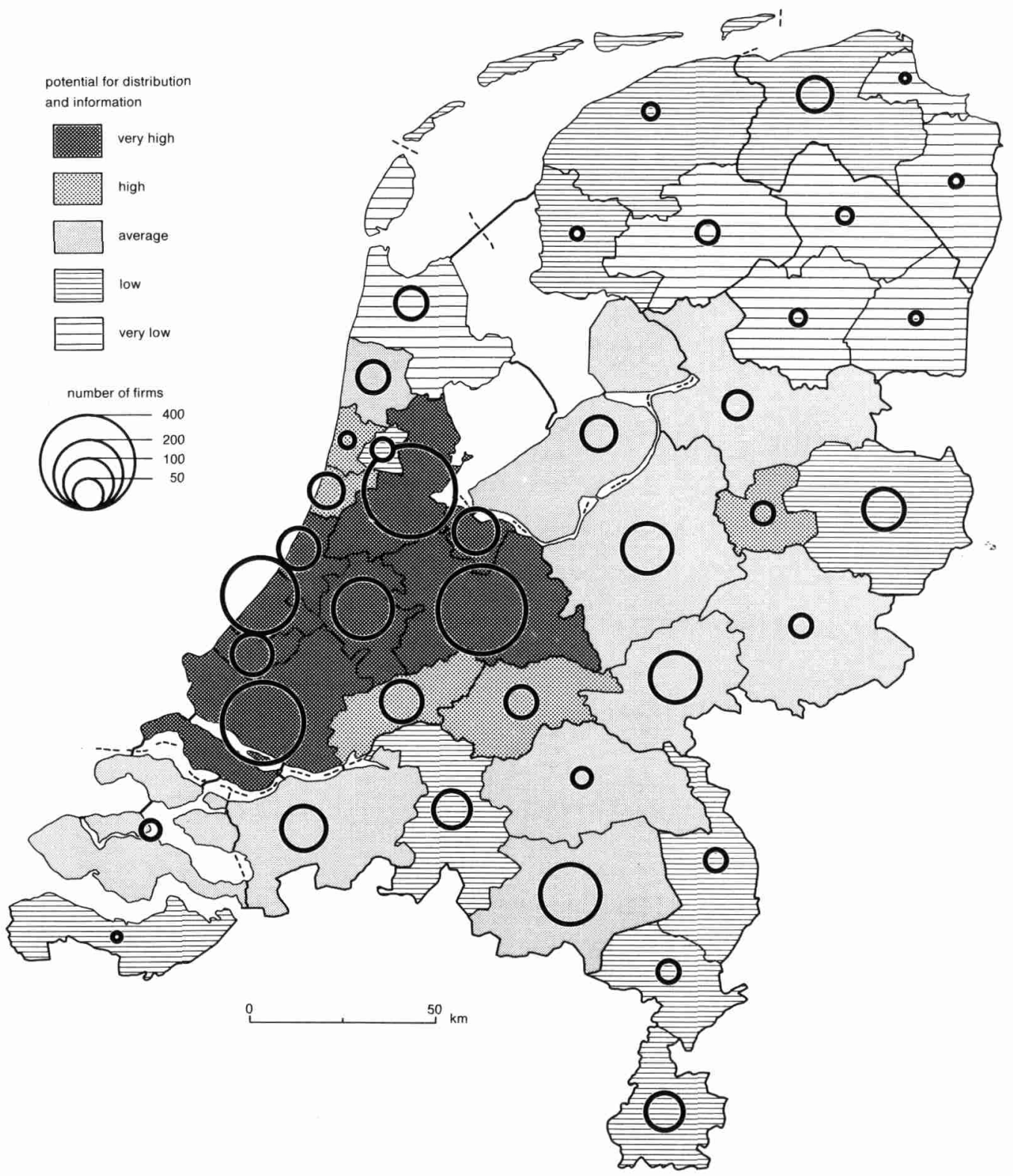

Note: the "potential for distribution and information" is calculated on the basis of employment in "promising" sectors of wholesale and quaternary services

Basic sources: G. A. v.d. Knaap \& P. J. Louter,

Variaties in economische gezondheid,

Erasmus University Rotterdam 1987.

D. Drenth, De informaticasector in Nederland, Geografisch Tijdschrift 1988-1

(c) P. H. Pellenbarg \& R. ter Brugge GIRUG Tijdschrift voor Econ. en Soc. Geografie 